\title{
The Adoption of the Negotiable Instruments Law in California
}

$\mathrm{T}$ HAT California has joined the overwhelming number of her sister states in the adoption of the Negotiable Instruments Law is cause for gratification; for in this state it supersedes an incomplete and unsatisfactory codification, the defects of which were pointed out by Professor Kidd in an article published in a previous number of this Review. ${ }^{x}$ It may now be helpful to call attention to some of the more practical results of this change in our law of negotiable instruments.

This Uniform Act was framed in 1895 under the direction of the Commissioners on Uniform State Laws. It was largely modeled upon the English Bill of Exchange Act, with such modifications as seemed advisable in view of American business conditions. In general, it is a codification of the common law, although in many instances it determines questions upon which the courts had disagreed, and in a few particulars it alters the common law rule. It is now in force in all but two of the states. $^{2}$

It would seem clear that, in view of its history and purpose, this statute should be interpreted so as to produce, as far as possible, uniformity in the law of the states adopting it, and to that end that decisions of other courts interpreting it should be given great weight, whereas local decisions, rendered before its enactment, should be disregarded except in so far as they may bear upon the meaning of its terms. Such, indeed, has been the attitude of the courts where they have considered the proper rule of interpretation ; and this attitude has been recently approved

1"The Law Merchant and California Decisions," by A. M. Kidd, 2 California Law Review, 377.

2 Georgia and Texas. Section 190 of the Act, as proposed, is as follows: "This act shall be known as the Negotiable Instruments Law." This section was omitted in Nebraska and California, and in Minnesota there was substituted the name "Uniform Negotiable Instruments Act," which is often used in referring to this statute.

3 See, for instance, Union Trust Co. v. McGinty (1912), 212 Mass. 205, 98 N. E. 679, Ann. Cas. 1913 C, 525; Cherokee National Bank v. Union Trust Co. (1912), 33 Okla. 342, 125 Pac. 464. 
by the United States Supreme Court, in dealing with a similar statute, the Uniform Warehouse Receipts Act.4 Unfortunately, however, many cases have been carelessly decided under local rules previously established, and without any regard to the provisions of the Act; and the cause of uniformity has been further injured by differences of opinion as to the interpretation of the statutory provisions. ${ }^{5}$

We may now compare the Uniform Act with the provisions of our Civil Code, bearing in mind that the Act does not apply to instruments made and delivered before July 27, 1917, the date when it took effect. ${ }^{\circ}$

What Instruments are Negotiable.-The general effect of the Act is to extend the character of negotiability to many instruments to which it was denied by the former provisions of our Civil Code, and the decisions thereunder. Negotiability is no longer affected by the following provisions: (1) for the payment of exchange, "whether at a fixed rate or the current rate"; (2) for "a confession of judgment if the instrument be not paid at maturity"; (3) for the waiver of the benefit of "any law intended for the advantage or protection of the obligor", including the homestead and exemption statutes. ${ }^{9}$ Moreover, the instru-

4 Commercial National Bank v. Canal-Louisiana Bank \& Trust Co. (1916), 239 U. S. 520, 60 L. Ed. 417, 36 Sup. Ct. Rep. 194. It is true that the Warehouse Receipts Act contains the following provision: "This act shall be so interpreted and construed as to effectuate its general purpose to make uniform the laws of those states which enact it." Cal. Stats. 1909, ch. $290, \S 57$. There is no such provision in the Negotiable Instruments Law; but the opinion in the Commercial Bank case is nevertheless of value as bearing upon the proper rule of interpretation of any of the uniform commercial statutes. It is to be noted that the title to the California statute adopting the Negotiable Instruments Law contains the following statement of its purpose: "An act to repeal title fifteen $\ldots$. and to add a new title fifteen .... and to make the law of Negotiable Instruments in the State of Califoruia uniform with the law of other states."

5 See the cases collected and discussed by Hon. A. M. Eaton at 78 Central L. Journal, 130; 12 Michigan Law Review, 89; 62 University of Pennsylvania Law Review, 407; 23 Yale Law Journal, 293.

${ }^{\circ} \mathrm{Cal}$. Civ. Code, \& $3266 \mathrm{~d}$ (195). Figures in parentheses following the references to the Civil Code in this note indicate the corresponding section of the original draft of the Negotiable Instruments Law.

${ }^{2}$ Cal. Civ. Code, \& 3083, subd. 4 (2, subd. 4).

8 Id. \$ 3086 , subd. 2 ( 5 , subd. 2$)$.

$\checkmark$ Id. $\$ 3086$, subd. 3 ( 5 , subd. 3 ). A note was held negotiable under the Act, although containing a waiver of all rights under homestead and exemption statutes, in Navajo County Bank v. Dolson (1912), 163 Cal. 485, 126 Pac. 153, 41 L. R. A. (N. S.) 787. 
ment may be drawn payable to the order of the holder of an office for the time being, and still retain its negotiability. ${ }^{10}$

The language of the Civil Code, as originally enacted, was held to prevent the inclusion in negotiable paper of a stipulation for the payment of attorneys' fees. ${ }^{11}$ This situation was remedied by the amendment of section 3088 in 1905, whereby it was enacted that a note might "provide for the payment of attorney's fees and costs of suit, in case suit be brought thereon to compel payment thereof." The provision of the Act in this regard is even more liberal, for it allows the note to call for "costs of collection and attorney's fee, in case payment be not made at maturity."12

Our Supreme Court had held that provisions accelerating the maturity of an instrument for non-payment of interest or installments destroyed negotiability. ${ }^{13}$ The contrary rule, that such provisions do not affect negotiability, is now established by the adoption of the Uniform Act. ${ }^{14}$

A very interesting question arises as to the effect of the Act on the negotiability of mortgage notes and bonds. The Supreme Court of California had held, in Meyer v. Webber ${ }^{15}$ and in a series of later decisions, ${ }^{16}$ that since in this state, under section 726 of the Code of Civil Procedure, the mortgaged property is the primary fund for the payment of debts secured by mortgage, and since the personal liability of the debtors upon such obligations is thereby rendered uncertain in amount, all

10 Cal. Civ. Code, $\S 3089$, subd. 6 (8, subd. 6).

11 Chase v. Whitmore (1886), 68 Cal. 545, 9 Pac. 942; Adams v. Seaman (1890), 82 Cal. 636, 23 Pac. 53; First Nat'l Bank v. Babcock (1892), 94 Cal. 96, 29 Pac. 415, 28 Am. St. Rep. 94; First Nat'l Bank v. Falkenhan (1892), 94 Cal. 141, 29 Pac. 866; Haber v. Brown (1894), 101 Cal. 445, 35 Pac. 1035; Kendall v. Parker (1894), 103 Cal. 319, 37 Pac. 401, 42 Am. St. Rep. 117; Mason v. Luce (1897), 116 Cal. 232, 48 Pac. 72; Findlay v. Pott (1901), 131 Cal. 385, 63 Pac. 694; Meyer v. Webber (1901), 133 Cal. 681, 65 Pac. 1110.

12 Cal. Civ. Code, § 3083, subd. 5 (2, subd. 5).

13 National Hardware Co. v. Sherwood (1913), 165 Cal. 1, 130 Pac.

881; Smiley v. Watson (1913), 23 Cal. App. 409, 138 Pac. 367; Wetzel v.

Cale (May 31, 1917), 53 Cal. Dec. 667, 165 Pac. 692.

11 Cal. Civ. Code, $\S 3083$, subd. 3 (2, subd. 3 ).

15 (1901), 133 Cal. 681, 65 Pac. 1110.

16 Briggs v. Crawford (1912), 162 Cal. 124, 121 Pac. 381 ; Helmer v. Parsons (1912), 18 Cal. App. 450, 123 Pac. 356; Mentry v. Broadway Co. (1912), 20 Cal. App. 388, 129 Pac. 470; National Hardware Co. v. Sherwood (1913), 165 Cal. 1, 130 Pac. 881; Taylor v. Jones (1913), 165 Cal. 108, 131 Pac. 114; Metropolis Bank v. Monnier (1915), 169 Cal. 592, 147 Pac. 265. 
notes secured by mortgage were non-negotiable. The surprise of the business community, when this rule was logically extended to cover corporate bonds, ${ }^{17}$ will be recalled; and also the subsequent amendment to section 3088 , whereby bearer bonds so secured were declared to be negotiable, leaving mortgage notes still nonnegotiable. ${ }^{18}$

The effect of the Uniform Act upon this situation is not entirely clear. Section 3088, so carefully anended to secure the negotiability of bearer mortgage bonds, has of course been repealed. ${ }^{19}$ It nay be urged that since uniformity of decision with other states is to be sought, and since the existence of mortgage security does not affect negotiability in the other states where the Act is in force, ${ }^{20}$ California should adopt the generally prevailing view and allow to mortgage obligations the privilege of negotiability. But the Act itself makes no mention of mortgage security. Furthermore, the California Legislature omitted the section of the Act which provides for the repeal of inconsistent legislation, ${ }^{21}$ and section 726 of the Code of Civil Procedure is thus left in full effect. If this section, as construed by the decisions already mentioned, ${ }^{22}$ be considered in connection with the general provisions of the Act requiring certainty of amount, the conclusion would seem to be inevitable that the existence of mortgage security prevents the secured paper, whether note or bond, from being negotiable. Further legislation upon the subject may be demanded by the business community; but in the meantime no prudent purchaser will rely on the negotiability of mortgage bonds issued subsequent to July 27, 1917.

The question of the negotiability under the new legislation, of bonds secured otherwise than by mortgage, affords an inter-

17 By the decision in Kohn v. Sacramento Electric Gas and Railway Co. (1914), 168 Cal. 1, 141 Pac. 626.

${ }_{18}$ This amendment was made in 1915 (Cal. Stats. 1915, p. 99) and consisted of the addition to section 3088 of the following proviso: "provided, however, that bonds payable to bearer shall be negotiable, notwithstanding any condition contained therein or in the mortgage, deed of trust or other instrument securing the same."

10 With the remainder of title fifteen of part four of division three of the Civil Code, by the Act adopting the Negotiable Instruments Law. Cal. Stats. 1917, p. 1531.

208 C. J. 200, and cases cited.

$21 \S 197$ of the original draft.

22 See cases cited under notes 15 and 16, supra. 
esting field for speculation. Formerly bonds were recognized as a distinct class of negotiable instruments by the express provisions of the Code. ${ }^{23}$ This provision has now been repealed, and the Act makes no mention of bonds whatever. As originally framed, the Act declared that in cases not provided for, the rules of "the law merchant" should govern;" and it has been suggested that this has the effect of adopting present mercantile custom on the question of negotiability. ${ }^{25}$ This suggestion (which might lead to the conclusion that bonds are negotiable because they are generally so considered by business men), would seem to be unsound, and it has been emphatically rejected by the California Legislature, which substituted for "the rules of the law merchant", "the rules of law and equity including the law merchant." 26 We may not, therefore, resort to business custom in determining the negotiability of bonds; but must confine ourselves to the common law, the Uniform Act and the unrepealed California Statutes.

It would seem reasonable to hold that a bond containing only a promise to pay a sum certain to bearer is in effect a promissory note and therefore negotiable, if it conforms to the rules codified and liberalized by the Uniform Act. Practically all of the later decisions accord with this view, which does no violence to the provisions of the Act. ${ }^{27}$

From a practical standpoint, the question will probably present itself in connection with bonds secured by a deed of trust. The question whether a deed of trust has the same effect as a mortgage in depriving the secured obligation of negotiability is undecided. ${ }^{28}$ Since the distinction between the two classes of security is well recognized in the decisions, ${ }^{29}$ and since section 726 of the Code of Civil Procedure does not apply to the enforcement of deeds of trust, there is good ground for the opinion that the

${ }^{23}$ Cal. Civ. Code, $\S 3095$, as it existed prior to its repeal in 1917.

$24 \$ 196$ of the original draft.

25 See discussion by Hon. A. M. Eaton, 12 Michigan Law Review, 89.

26 Cal. Civ. Code, \$ 3266d (196).

${ }^{27}$ See Edelstein v. Schuler (1902), 2 K. B. 144; Mercer County v. Hacket (1863), 1 Wall. 83, 95; and see comment on these cases in 2 California Law Review, 377, at p. 390. See also cases cited 10 Cyc. 1172.

28 This question was stated to be an open one in Smiley v. Watson (1913), 23 Cal. App. 409, 138 Pac. 367.

29 Grant v. Burr (1880), 54 Cal. 298; Younger v. Moore (1909), 155 Cal. 767, 103 Pac. 221. 
mere existence of security in the form of a trust deed would not affect the negotiability of the secured note or bonds. But if the deed of trust contains a provision, express or implied, requiring a sale of the property before action can be brought on the principal obligation, it would probably be rendered nonnegotiable, for the same reason that paper secured by mortgage is in this state held to be non-negotiable. In the absence of some such provision, the question of the negotiability of bonds secured by deeds of trust will in most cases depend on whether, for this purpose, stipulations contained in the deed of trust, (as for the care of the property, the payment of taxes, or the securing of insurance) should be considered as part of the bond. If so, negotiability would be destroyed by the many covenants contained in the usual form of deed of trust. In some states the general view has been that, although in a sense the deed of trust and bond may be considered as one contract, nevertheless the bonds may be collected without enforcing the security and their negotiability is in no wise affected by the covenants in the trust deed. ${ }^{30}$ A well-reasoned case which adopts this view, in the case of a mortgage note, is Thorpe v. Mindeman, ${ }^{31}$ decided in Wisconsin under the Negotiable Instruments Law. However, the contrary rule, which imports into the note or bond the provisions of the instrument of security for the purpose of determining the question of negotiability, has been adopted by some decisions, including that of Meyer $v$. Webber ${ }^{32}$ in California. If our Supreme Court should now follow the rule there declared, practically all bonds secured by trust deeds will be held nonnegotiable. A different view might be taken upon a reconsideration of the question, in order to conform to the great weight of authority where the Uniform Act is in force; but in the present condition of the law, the negotiability of this class of bonds is subject to extreme doubt.

Certificates of deposit were also named by the Civil Code as a class of negotiable paper, ${ }^{33}$ but are not mentioned in the Negotiable Instruments Law. Under the decisions from other

30 The cases on both sides of this question are collected at 8 C. J. 201.

$a_{1}$ (1904), 123 Wis. 149, 101 N. W. 417, 107 Am. St. Rep. 1003, 68 L. R. A. 146 .

32 (1901), 133 Cal. 681, 65 Pac. 1010.

33 Cal. Civ. Code, $\S 3095$, as it existed prior to its repeal in 1917. 
states, there seems to be no occasion to doubt that if a certificate of deposit be in negotiable form, and conforms otherwise to the provisions of the Act, it is as negotiable as the usual form of promissory note. ${ }^{34}$

Frequently it is provided in notes that the time of payment may be extended without affecting the liability of the parties; or the note may contain an express consent to any extension of time which may be given. The courts have disagreed as to whether these provisions destroy negotiability, under the requirement of the Negotiable Instruments Law that the paper must be payable "on demand, or at a fixed or determinable future time". ${ }^{35}$ Certainly, if the extension is only to occur after maturity, there is no violation of this rule; and it was so held by the Supreme Court of California in Navajo County Bank v. Dolson, ${ }^{38}$ in passing upon the negotiability of a note governed by the provisions of the Act. But if the parties consent to an extension before maturity, the authorities are in direct conflict as to the effect upon negotiability, ${ }^{37}$ although the better reasoning seems to support the view favoring negotiability.

Under the former code provisions, ${ }^{38}$ and also under the Uniform Act, ${ }^{39}$ a provision for the sale of collateral security may be present in a note, without affecting its negotiability. May the note also include a provision for the substitution of other security, in case the collateral depreciates in value, and that in default of satisfactory security, the instrument shall mature at once? Two courts have held that this is an additional contract, not allowable in negotiable paper under the terms of the Act;:0

34 Kavanagh v. Bank of America (1909), 239 Ill. 404, 88 N. E. 171; First National Bank v. Stapf (1905), 165 Ind. 162, 74 N. E. 987, 112 Am. St. Rep. 214.

${ }_{35}$ Cal. Civ. Code, $\$ 3082$, subd. 3 (1, subd. 3 ).

${ }^{36}$ (1912) 163 Cal. 485,126 Pac. 153, 41 L. R. A. (N. S.) 787; Stitzel v. Miller (1911), 250 III. 72,95 N. E. 53, 34 L. R. A. (N. S.) 1004, is in accord.

87 The following cases hold that this stipulation is fatal to negotiability: Rossville State Bank v. Heslett (1911), 84 Kan. 315, 113 Pac. 1052 , 33 I. R. A. (N. S.) 738; Union Stockyards Nat'l Bank v. Bolan (1908), 14 Ida. 87, 93 Pac. 508. Contra, Farmer v. Bank of Graettinger (1906), 130 Iowa 469, 107 N. W. 170; First Nat'l Bank v. Buttery (1908), 17 N. D. 326, 116 N. W. 341, 16 I. R. A. (N. S.) 878.

38 Cal. Civ. Code, $\$ 3092$, as it existed prior to its repeal in 1917.

${ }^{39}$ Id. $\$ 3086$, subd. 1 (5, subd. 1$)$.

10 Holliday State Bank v. Hoffman (1911), $85 \mathrm{Kan} .71,116$ Pac. 239, 35

L. R. A. (N. S.) 390, Ann. Cas. 1912 D 1; Hibernia Bank and Trust Co. v. 
while two other courts have held that it did not affect the negotiability of the paper, being a mere incident to the pledge.41 There is no California authority upon the point.

Our courts may also be called upon to decide the mooted question whether an instrument allowing a discount for payment before maturity, is one for the payment of a "sum certain".42 On all of these questions it is to be hoped that the California courts will be liberally inclined towards negotiability.

Form and Interpretation of Negotiable Instruments.-The Act provides that "the signature of any party may be made by a duly authorized agent", and further that "no particular form of appointment is necessary for this purpose." 43 This would seem to be a change in our law, which, by section 2309 of the Civil Code, provides generally that the authority of an agent to enter into a contract required to be in writing must likewise be in writing. In Kentucky the Uniform Act was amended so as to require written authority in the case of negotiable instruments. ${ }^{44}$

Formerly, if the instrument did not provide for the date from which interest was to run, it commenced to run only at maturity, ${ }^{45}$ whereas under the Act, it will run from the date of the instrument, or if undated, from the time of its issue. ${ }^{46}$

A recent decision of a District Court of Appeal ${ }^{47}$ in the case of Payne v. Commercial National Bank held that in case of a conflict between the words and figures of a negotiable instrument, the figures might be made to control the words by parol evidence. A hearing of this case has been granted by the Supreme Court; but the rule laid down by the District Court of Appeal, which is at variance with cases in other states ${ }^{48}$ and with

Dresser (1913), 132 La. 532, 61 So. 561 ; Continental Bank \& Trust Co. v. Baker (1913), 132 La. 544,61 So. 575.

41 Finley v. Smith (1915), $165 \mathrm{Ky} .445,177$ S. W. 262, L. R. A. 1915 F 777 ; Kennedy v. Broderick (1914), 216 Fed. 137, L. R. A. 1915 B 472.

42 See Farmers' Loan \& Trust Co. v. Planck (1915), 98 Neb. 225, 152

N. W. 390 , L. R. A. 1915 E. 564 , upholding the negotiability of such a note; and Farmers' Loan \& Trust Co. v. McCoy (1912), 32 Okla. 277, 122 Pac. 125,40 L. R. A. (N. S.) 177, contra.

${ }_{43}$ Cal. Civ. Code, $\$ 3100$ (19).

44 See Finley v. Smith (1915), $165 \mathrm{Ky} .445,177 \mathrm{~S}$. W. 262, L. R. A. 1915 F 777.

15 Cal. Civ. Code, § 1917. See also Jones v. Gardner (1881), 57 Cal. 641 ;

City of Los Angeles v. City Bank (1893), 100 Cal. 18, 34 Pac. 510.

${ }^{46}$ Cal. Civ. Code, \$ 3098, subd. 2 (17, subd. 2 ). 
generally recognized commercial custom, cannot be followed in future cases by reason of the provision of the Act that the words control in such a case, unless they be ambiguous or uncertain, in which case reference may be made to the figures. ${ }^{49}$

Negotiation and Transfer.-If negotiable paper has been indorsed in blank, and the holder wishes it to be transferable only by indorsement, he may unquestionably write above the indorsement an effective direction to pay to a particular person. This common law rule was re-stated by our Civil Code, ${ }^{50}$ and by the Negotiable Instruments Law. ${ }^{51}$ If the holder, however, does not choose to avail himself of this right, but merely writes a special indorsement after the blank indorsement, what will be the effect? At common law the paper remained negotiable by delivery; and the only effect of the special indorsement was to protect the special indorser against liability to persons not tracing title through the indorsement of the special indorsee.52 The former California code rule went further and declared that a special indorsement could not be made after a general indorsement, thereby apparently establishing the rule that for all purposes the paper remained negotiable by delivery. ${ }^{53}$ The Negotiable Instruments Law contains two provisions on the subject, section 9 (subdivision 5) providing that "the instrument is payable to bearer .... when the only or last indorsement is an indorsement in blank"," and section 40 that "when an instrument, payable to bearer, is indorsed specially, it may nevertheless be further negotiated by delivery; but the person indorsing specially is liable as indorser to only such holders as make title through the indorsement." Court.

47 (May 21, 1917), 24 Cal. App. Dec. 881, now pending in the Supreme 48 Smith v. Smith (1850), 1 R. I. 398; National Bank v. Second National Bank (1880), 69 Ind. 479, 35 Am. Rep. 236; Daniel on Negotiable Instruments, $\$ 86$ and cases cited.

49 Cal. Civ. Code, $\$ 3098$, subd. 1 (17, subd. 1).

so Id. \& 3114, as it existed prior to its repeal in 1917.

s1 Id. \$ 3116 (35).

52 Smith v. Clarke (1794), Peake 225, 1 Esp. 180; Walker v. McDonald (1848), 2 Ex. 527; Habersham v. Lehman (1879), 63 Ga. 380; Howry v. Eppinger (1876), 34 Mich. 29; Mitchell v. Fuller (1850), 15 Pa. St. 268; Johnson v. Mitchell (1878), 50 Tex. 212.

${ }_{53}$ Id. $\$ 3114$, as it existed prior to its repeal in 1917.

54 Id. $\$ 3090$, subd. 5.

so Id. § 3121 . 
two sections were repugnant, that section 9 was intended to abrogate the common law rule, while section 40 would re-enact this rule..$^{56}$ If this contention be sound, section 40 would control, not only as the later section, but also because it is more specific in its terms. Mr. McKeehan suggests that the two sections may be reconciled by confining section 9 to paper which was originally payable to bearer, and allowing section 40 to apply to cases where order paper had been indorsed in blank. ${ }^{57}$ This view calls for a considerable straining of the statutory langnage. But whichever interpretation may be the correct one, it is interesting to note that despite the keen and protracted argument upon the point, twenty years have now elapsed since the first enactment of the Uniform Act, without a single case involving the question having been reported.

Rights of Holder in Due Course.-The "indorsee in due course" of the code becomes the "holder in due course" of the Uniform Negotiable Instruments Act, both forms of codification doing away with the latinity of the older titles.

The Act definitely establishes what seems to have been the previous law of California, that a pre-existing debt is sufficient consideration to clothe the creditor who is secured or paid by the instrument with the rights of such a holder. ${ }^{58}$ It is interesting to note that some of the New York cases have refused to give effect to the plain language of the Act in this regard. ${ }^{59}$

There was formerly a sharp conflict of authority as to whether the defense of want of delivery might be asserted against a holder in due course, where the instrument was stolen or otherwise obtained from the maker without his consent. ${ }^{60}$ This

58 14. Harvard Law Review, 241; 14 Harvard Law Review, 442. See reprint in Brannan on Negotiable Instruments Law.

s7 41 American Law Register, pp. 437, 499, 561. See reprint in Brannan on Negotiable Instruments Law.

58 Cal. Civ. Code, $\S 3106$ (25).

59 Bank of America v. Waydeil (1905), 92 N. Y. Supp. 666; Carpenter v. Hoadley (1910), $123 \mathrm{~N}$. Y. Supp. 61. The tendency of the later case is to give effect to the provisions of one Act. See opinion in Brown v. Rowan (1915), 154 N. Y. Supp. 1098, wherein the court comments on the desirability of conformity and the effect to be given to decisions from other states.

${ }_{60}$ The cases on this point are cited in notes at 8 C. J. 754. For the view that want of delivery is a real defense, which may be asserted against all parties, see Salley v. Terrill (1901), 95 Me. 553, 50 Atl. 896, 85 Am. St. Rep. 433, 55 L. R. A. 730 . For the contrary view, that a 
question had not been passed upon in this state; but the Negotiable Instruments Law now protects the holder in due course against the defense of want of delivery under these circumstances. ${ }^{61}$

A striking change has been made with respect to the time within which a person without notice of actual dishonor must purchase demand paper in order to occupy the position of a holder in due course. The common law required a purchase within a reasonable time after issuance. Our code substituted a time of apparent maturity, which was arbitrarily fixed at ten days in the case of demand or sight bills without interest (in addition to the time for forwarding), six months in the case of notes payable without interest, and one year upon interestbearing paper. ${ }^{.2}$ The Uniform Law restores the common law rule in California; ;3 and the convenient rule-of-thumb of the Field code is thus sacrificed in the interest of uniformity. This rule of "rreasonable time" of purchase now extends to checks, which could formerly be taken after the apparent maturity without the purchaser's losing the rights of a holder in due course. ${ }^{64}$

Can the payee of a negotiable instrument be a holder in due course? At common law he could under some circumstances; for if $A$ was induced by the fraud or other wrongful conduct of $B$ to hand him a negotiable note payable to the order of $C$, and $C$ paid value for the note in good faith, $A$ could not assert against $C$ his personal defense against $B^{.5}$ The language of the Negotiable Instruments Law does not seem to afford protection to the innocent payee under these circumstances; for in order that a person may be a holder in due course, it requires "that at the time it was negotiated to him he had no notice of any infirmity in the instrument." In some states it has been held that since the Act contemplates a negotiation to the holder

holder in due course takes free from this defense, see Shipley v. Carroll (1867), 45 I11. 285; Kenyon v, Wohlford (1871), 17 Minn. 239, 10 Am. Rep. 165.

61 Cal. Civ. Code, § 3097 (16).

62 Id. $\S \S 3123,3134-3136$, as they existed prior to their repeal in 1917. 03 Id. \& 3134 (53). in 1917.

64 See Cal. Civ. Code, $\S 3255$, subd. 2, as it existed prior to its repeal

os Watson v. Russell (1862), 3 B. \& S. 34, 122 Eng. Rep. R. 14; Gagle v. Lane (1887), 49 Ark. 465, 5 S. W. 790 ; Lamson v. Beard (1899), 94 Fed. 30, 45, L. R. A. 822.

${ }_{66}$ Cal. Civ. Code, $\S 3133$, subd. 4 (52, subd. 4). 
in due course, and since an instrument cannot be said to have been "negotiated" to the payee, he cannot be a holder in due course under its provisions. ${ }^{6 \tau}$ The contrary result has been reached in Alabama, Massachusetts and New York, where the courts are willing to extend the statutory language to cover this case because of their belief that in this regard the Act was intended to codify the common law. ${ }^{68}$ There is a similar lack of uniformity in the English decisions construing the corresponding sections of the Bill of Exchange Act. ${ }^{69}$

At common law, a material alteration constituted a real defense, which might be asserted even against a purchaser in good faith; and this rule obtained in California. ${ }^{70}$ It is now modified by the provision of the Uniform Act that "when an instrument has been materially altered and is in the hands of a holder in due course, not a party to the alteration, he may enforce payinent thereof according to its original tenor." ${ }^{\prime 1}$

Liability of Parties. - The only parties whose liability is substantially affected by the adoption of the Uniform Act are the indorser without recourse, or qualified indorser, and the transferor without indorsement. Under our Civil Code provisions, these parties warranted only their title and their want of knowledge of any facts which would tend to prove the instrument worthless. ${ }^{22}$ They now guarantee in addition that the instrument is genuine and in all respects what it purports to be and that all prior parties had capacity to contract. ${ }^{73}$ The implied warranty of the indorser without recourse now runs in favor of any holder of the paper, whereas that of the transferor by delivery continues to run only

67 Vander Ploeg v. Van Zuuk (1907), 135 Iowa 350, 112 N. W. 807, 124 Am. St. Rep. 275, 13 L. R. A. (N. S.) 490; St. Charles Bank v. Edwards (1912), 243 Mo. 553, 147 S. W. 978; Gresham Bank v. Walch (1915), 76 Ore. 272, 147 Pac. 534

68 Ex parte Goldberg v. Lewis (1914), 191 Ala. 356, 67 So. 839; Liberty Trust Co. v. Tilton (1914), 217 Mass. 462, 105 N. E. 605, L. R. A. 1915 B 144; Brown v. Rowan (1915), 154 N. Y. Supp. 1098.

69 See Herdman v. Wheeler (1902), 1 K. B. 361, adverse to the payee's rights as a holder in due course; and Lloyd's Bank v. Cooke, [1907] 1 K. B. 794 , contra.

${ }^{70}$ Walsh v. Hunt (1898), 120 Cal. 46, 52 Pac. 115, 39 L. R. A. 697.

71 Cal. Civ. Code, $\$ 3205$ (124).

72 Id. $\$ \S 1765,1774,3118$, as it existed prior to its repeal in 1917.

73 Id. $\$ 3146(65)$. The warranty of the capacity of prior parties to contract does not apply to cases of transfers of public or corporate bonds. 
to his immediate transferee. ${ }^{74}$ The liability of the unqualified indorser is practically the same as before. ${ }^{75}$

The Act codifies the decisions which hold that the certification of a check at the instance of a holder results in the release of the drawer and indorsers. ${ }^{76}$ Whether this rule formerly obtained in California is subject to doubt in view of section 3255 , which provided that a check is subject to the code provisions concerning bills of exchange.

A novel provision, of considerable practical importance, is that of section 87, to the effect that if an instrument be made payable at a bank, "it is equivalent to an order to the bank to pay the same for the account of the principal debtor thereon."'77 In two states this section has been omitted; and it was the occasion for some opposition to the adoption of the Act in California.

Presentment and Notice of Dishonor.-The most noticeable change with regard to presentment and notice of dishonor has to do with demand paper. Formerly, presentment of such paper was required to be made within the arbitrary periods fixed by code provisions, already mentioned, being ten days in the case of demand or sight bills without interest, six months in the case of notes without interest, and one year where the paper provided for interest. ${ }^{78}$ This is no longer the law, for the Act restores the common law rule that demand paper must be presented within a reasonable time, and adds the novel provisions that "in the case of a bill of exchange, presentment for payment will be sufficient if made within a reasonable time after the last negotiation thereof." 79

With regard to the time of presentment of checks, the law of California, prior to the passage of the Act, was somewhat

74 Id. $\$ 3146$ (65).

75 Compare the provisions of Cal. Civ. Code, $\$ 3147$ (66) with the former provisions of $\S 3116$, prior to its repeal in 1917.

${ }^{70}$ Id. \& $3265 \mathrm{~d}(188)$.

77 Id. \$ 3168 (87).

78 Id. \$\$ 3133-3136, 3189, 3213, Civil Code, as they existed prior to their repeal in 1917. See Machado v. Fernandez (1887), 74 Cal. 362, 16 Pac. 19, wherein it was said that in the case of interest-bearing demand paper, no delay in presentment would release the indorsers. But this decision is treated as overruled by the later cases. Wills v. Booth (1907), 6 Cal. App. 197, 91 Pac. 759.

${ }^{79}$ Cal. Civ. Code, $\$ 3152$ (71). See also, as to presentment for acceptance, § 3225 (144). 
in doubt. The Code provisions would seem to indicate that the same rule should be applicable to checks as to demand bills, which would only require presentment within ten days, in addition to the time for forwarding. ${ }^{80}$ Nevertheless, the District Court of Appeal for the Second District, had delivered a strong dictum $^{81}$ to the effect that the holder was required to present within a reasonable time, under the common law rule; that this time was ordinarily one day, in addition to the time for forwarding, and that Section 3213, which fixed the ten day period, merely had the effect of fixing a limit beyond which the reasonable time could not be held to extend. Whatever may have been the correct interpretation of these provisions, the Act now provides that "a check must be presented within a reasonable time after its issue or the drawer will be discharged from liability thereon to the extent of the loss caused by the delay."82 Apparently, the common law rule releasing indorsers absolutely for failure to present within a reasonable time is now in force. ${ }^{83}$

Under the provisions of the Act, an indorser of overdue paper is in the same position as an indorser of demand paper; and is therefore entitled to insist upon presentment within a reasonable time. ${ }^{84}$ The same result had been reached by our Supreme Court in the case of Beer v. Clifton, ${ }^{85}$ although it was intimated in that case that the time of apparent maturity was the limit of time for presentment. Notice of dishonor is no longer required to be in writing, and there are some slight changes as to the time of giving notice. ${ }^{86}$

Maurice E. Harrison.

University of California,

Berkeley, California.

80 Id. $\S 3213$, apparently made applicable to checks by $\S 3255$, as those sections existed prior to their repeal in 1917.

81 R. H. Herron Co. v. Mawby (1907), 5 Cal. App. 39, 89 Pac. 872.

82 Cal. Civ. Code, $\$ 3265 \mathrm{~b}$ (186).

83 Kirkpatrick v. Puryear (1894), 93 Tenn. 409, 24 S. W. 1130, 22

L. R. A. 785 and note; Start v. Tupper (1908), 81 Vt. 19, 69 Atl. 151, 15

L. R. A. (N. S.) 213.

84 Cal. Civ. Code, \& 3088 (7). 580.

85 (1893), 98 Cal. 323, 33 Pac. 204, 35 Am. St. Rep. 172, 20 L. R. A.

86 The notice of dishonor may be in writing or merely oral. Càl. Civ. Code, § 3177 (96). See also Smith v. Hirst (1917), 32 Cal. App. 507, 163 Pac. 334. 